\title{
Application of Citric Acid, Sodium Chloride and Peroxyacetic Acid as Alternative Chemical Treatment for Organic Trimmed Aromatic Coconut
}

\author{
Diem Thi Ngoc Nguyen', Kullanart Tongkhao', \\ and Sasitorn Tongchitpakdee ${ }^{1,2^{*}}$
}

${ }^{1}$ Department of Food Science and Technology, Faculty of Agro-Industry, Kasesart University, Bangkok 10900, Thailand

${ }^{2}$ Postharvest Technology Innovation Center, Commission on Higher Education, Bangkok 10400, Thailand

*Corresponding author.E-mail: sasitorn.ch@ku.th

https://doi.org/10.12982/CMUJNS.2019.0030

Received: November 15, 2018

Revised: March 8, 2019

Accepted: March 20, 2019

\begin{abstract}
Shelf-life of trimmed coconut is usually extended using sulfite agents or chlorine. However, in organic produce, applications of sulfite agents is prohibited while chlorine is restricted. The objective of this study was aimed to extend the shelf-life of organic trimmed aromatic coconut using citric acid (CA), sodium chloride ( $\mathrm{NaCl}$ ) and peroxyacetic acid (PAA). Organic trimmed aromatic coconuts were dipped in $C A(10 \%$ and $20 \%)$ in combination with $\mathrm{NaCl}$ (10\% and 15\%) followed by dipping in PAA (80 ppm). All samples were compared with control (no dipping) and those dipped in 3\% sodium metabisulfite (SMS). During 8 weeks of storage at $2^{\circ} \mathrm{C}$, qualities of treated coconuts including visual quality, color values $\left(L^{*}, a^{*}, b^{*}\right)$ and total plate count (TPC) on surface of samples were evaluated. Chemical qualities (titratable acidity (TA), $\mathrm{pH}$ and total soluble solids) of coconut water were also determined. The results showed that beside SMS, treatment $20 \% \mathrm{CA}+15 \% \mathrm{NaCl}$ was the most effective treatment for maintaining visual quality and color as well as controlling microbial growth $(P<0.05)$. Moreover, PAA treatment could only help reducing the TPC up to five weeks of storage and resulted in yellowish color. Therefore, $20 \% \mathrm{CA}+15 \% \mathrm{NaCl}$ could be an alternative chemical treatment in controlling postharvest deterioration of organic trimmed aromatic coconut.
\end{abstract}


Keywords: Organic trimmed aromatic coconut, Citric acid, Peroxyacetic acid, Shelf-life, Sodium chloride

\section{INTRODUCTION}

'Aromatic Green Dwarf' or 'Nam Hom' coconut is one of the most important exported plant which contribute to the economy of Thailand. The key aroma compounds of water and meat of this fruit are similar to pandan leaf (Jangchud et al., 2007). There are three types of organic aromatic coconut usually exported to other countries: green, trimmed and polished aromatic coconut. Trimmed coconut is very popular due to convenience and transportation cost reduction (Mohpraman and Siriphanich, 2012). However, by removing outer layer, trimmed coconut has shorter shelf-life due to microbial spoilage and surface discoloration caused by enzymatic browning.

Consumption of organic aromatic coconut has dramatically increased due to consumers' concern about possible health risks and environmental impacts of conventional produce production methods. According to US regulation, organic produce are required to be produced and processed without synthetic pesticides, growth hormones, antibiotics, modern genetic engineering techniques, hemical fertilizers, or sewage sludge (Winter and Davis, 2006). Recently, sulfite agents (e.g. sodium metabisulfite, potassium metabisulfite, sulfur dioxide, sodium sulfite and sodium bisulfite) and chlorine are commonly used to extend shelf-life of trimmed aromatic coconut. However, sulfite agents and chorine were reported to cause allergenic effects (Vally et al., 2009; Abadias et al., 2011). Consequently, the application of sulfite agents were prohibited and levels of chlorine residue for wash water in direct crop or food contact were limited not exceed 4 ppm) (CFR, 2011). Therefore, it is necessary to develop a better treatment to maintain quality of organic trimmed aromatic coconut.

Previously, there are many studies on sulfite substitutes for fresh produces such as ascorbic acid (Javdani et al., 2013), 4-hexylresorcinol (Hexyl), calcium chloride $\left(\mathrm{CaCl}_{2}\right)$ (Ghidelli et al., 2013), sodium chlorite (Lu et al., 2007) or combination of inhibitors and sanitizer (Wang et al., 2007). Among safe and widely used additives, citric acid (CA) and sodium chloride $(\mathrm{NaCl})$ were reported to help prolonging quality of fresh-cut products (Plaza et al., 2003; Manolopoulou and Varzakas, 2011; Park et al., 2011). Nonetheless, chemical treatments have limited success in extending the shelf life of product because of low efficiency, off flavors, and injury (Lu et al., 2007). Peroxyacetic (PAA), a mixture of acetic acid $\left(\mathrm{CH}_{3} \mathrm{COOH}\right)$ and hydrogen peroxide $\left(\mathrm{H}_{2} \mathrm{O}_{2}\right)$ in an aqueous solution, is considered giving positive effect towards novel way to improve microbiological stability fresh produce and could be used as chlorine substitution (Fawell, 2000). 
However, little information has been published concerning impact of various concentrations of citric acid and sodium chloride, individually or in combination with a PAA, on browning and microbial quality of trimmed aromatic coconut. Therefore, this study was conducted to evaluate the efficacy of citric acid, sodium chloride and PAA, alone and in combination, on quality of organic trimmed aromatic coconut at an ideal storage temperature.

\section{MATERIALS AND METHODS}

\section{Raw material and preparation}

Organic aromatic coconuts were harvested 6-7 months after inflorescence in Samutsakorn Province, Thailand. Then, the coconuts were delivered to a packing house located in the same area. After arriving the packing house, the fruits were trimmed with a sharp knife starting from the conical top and cylindrical body to the flat base. 540 coconut fruits that weight approximately $1,200 \mathrm{~g}-1,500 \mathrm{~g} /$ fruit were used in this study

\section{Chemical treatment and dipping process}

Citric acid (food grade, Sunshine Biotech International Co., Ltd, Prachinburi, Thailand) at concentration $10 \%$ and $20 \%(\mathrm{w} / \mathrm{v})$ and $\mathrm{NaCl}$ at $10 \%$ and $15 \%(\mathrm{w} / \mathrm{v})$ were used in combination as an alternative treatments in this study. After trimming, coconuts were immediately dipped in treatment solutions for $10 \mathrm{~min}$ at room temperature. Half of each treated samples were subsequently dipped in PAA (80 ppm; Tsunami 100; Ecolab, St Paul, Minn., U.S.A., prepared according to the manufacturer's instruction) for two minutes followed by rinsing with tap water (CFR, 2011). After dipping, coconuts were blotted using a clean paper towel and wrapped with PVC film. All samples were stored at $2 \pm 2{ }^{\circ} \mathrm{C}$ for 8 weeks. Initial analysis were conducted within eight hours after dipping. Sulfite treatment (sodium metabisulfite; SMS 3\%) and control (no dipping) were used for comparison.

\section{Visual quality assessment}

Visual quality assessments was conducted using method modified from Amodio et al. (2007) and Cabezard-Serrano et al. (2009). The evaluation was subjectively assessed by a group of 3 judges, using as a photographic reference scale associated with brief descriptions (Amodio et al., 2007; Cabezas-Serrano et al., 2009). The scale was set up based on appearance of samples and rated according to the industry practices. The quality rating scale was $5=$ excellent (white color and free of decay), $4=\operatorname{good}$ (creamy in color with $10 \%$ browning on whole coconut surface and free of decay), 3 = fair (limit of marketability, 25\% 
browning on whole coconut surface and free of decay), 2 = poor (10\% browning on whole coconut surface and less than or equal to $25 \%$ decay) and $1=$ very bad (more than $25 \%$ browning on whole coconut surface and more than $25 \%$ decay).

The coconuts of treatments which were scored lower than acceptability limit (visual quality score $<3.0$ ) were not further analysed for quality parameters during storage.

\section{Color analysis}

Surface color of trimmed coconut was directly measured using a colorimeter (Ultra Scan PRO Hunter Lab spectrophotometer, USA). CIE L*a*b values were measured using reflectance mode. Total color difference $\left(\Delta \mathrm{E}^{*}\right)$ and browning index $(\mathrm{BI})$ were calculated according to Equation 1 and 2, respectively (Hunter and Harold, 1987).

$$
B I=\frac{x-0.31}{0.172} \times 100
$$

When $x=(a+1.75 L) /(5.645 L+a-3.012 b)$

$$
\Delta E=\sqrt{\Delta a^{2}+\Delta b^{2}+\Delta L^{2}}
$$

Three coconut fruits of each treatment were sampled weekly. In each fruit, 15 readings were conducted from different positions on the whole fruit surface.

\section{Microbiological analysis}

Total plate count (TPC) was determined using swab test on surface of trimmed coconut by sterile cotton swab. Serial dilutions were prepared in sterile $0.1 \%$ peptone solution (Merck, Germany) and spread on duplicate plates of plate count agar (Merck, Germany) (Anderton, 1986). The plates were incubated for $48 \mathrm{~h}$ at $35 \pm 2{ }^{\circ} \mathrm{C}$. Microbial counts were expressed as log CFU/fruit. Three coconut fruits of each treatment were sampled every week of storage time.

\section{Titratable acidity (TA), pH and total soluble solids (TSS) analysis}

The coconut water was analyzed in triplicate for all parameters. The measurement were taken in control temperature room at $25^{\circ} \mathrm{C}$. TA of coconut water was determined using method of AOAC (962.12) in juice and wine (AOAC, 2000). The coconut water was titrated with $0.1 \mathrm{~N} \mathrm{NaOH}$ until a faint pink reached (maintained for $30 \mathrm{~s}$ ). TA was expressed as percentage of malic acid 
$(\mathrm{w} / \mathrm{v}) \cdot \mathrm{pH}$ value was measured using $\mathrm{pH}$ meter (Thermo Scientific ${ }^{\mathrm{TM}}$ Orion $^{\mathrm{TM}}$ 2-Star Benchtop, USA). TSS of coconut water was determined with a hand held refractometer (Mater-T, Atago, Japan) and expressed as ${ }^{\circ}$ Brix (AOAC, 2000).

\section{Statistical analysis}

The whole experiment were conducted twice. The experimental design was a factorial complete randomized design with storage time and treatment as factors. The data were recorded and analyzed by SPSS version 16 software (IBM Corp., USA). Differences among means were analyzed by two-way analysis of variance (ANOVA) and mean comparison was conducted using Duncan's News Multiple Range Test. Differences between means at 5\% $(P<0.05)$ level was considered significantly.

\section{RESULTS}

\section{Influence of treatments on visual quality of trimmed organic aromatic coconut}

Visual quality scores clearly showed that all of treatments helped maintaining appearances of organic trimmed aromatic coconuts better than the control during 8-week storage (Figure 1). At week 0, the control sample was rated lower significantly than other treatments (in range of 3.65-5) due to rapid color changing after few hours $(P<0.05)$.

The marketability limit of samples treated with $10 \% \mathrm{CA}+10 \% \mathrm{NaCl}$, and $10 \% \mathrm{CA}+15 \% \mathrm{NaCl}$ were 6 weeks at $2{ }^{\circ} \mathrm{C}$. Dipping in PAA could help to extend marketability of samples of $10 \% \mathrm{CA}+10 \% \mathrm{NaCl}$, and $10 \% \mathrm{CA}+15 \%$ $\mathrm{NaCl}$ longer from 3 days ( 0.5 week) and 10 days (1.5 week), respectively compared to treatment without dipping in PAA samples under storage at $2{ }^{\circ} \mathrm{C}$. Treatment $20 \% \mathrm{CA}+15 \% \mathrm{NaCl}$ had higher overall appearance compared to other treatments $(P<0.05)$ and always followed SMS to maintain the scores higher than marketability limit during storage time, especially at the last week of storage. It seem that citric acid and sodium chloride at high concentration provided long term effect on maintaining visual quality score better than that at low concentration during storage at $2{ }^{\circ} \mathrm{C}$. PAA did not help treatments $20 \%$ $\mathrm{CA}+10 \% \mathrm{NaCl}$ and $20 \% \mathrm{CA}+15 \% \mathrm{NaCl}$ but the treatments themselves could maintain the acceptability rating until the end of storage as SMS treatment.

The sample of treatments, which were rated lower than marketability limit, were not continuously analysed in other parameters including color, $\mathrm{pH}$, TA, TSS and microbial analysis. 


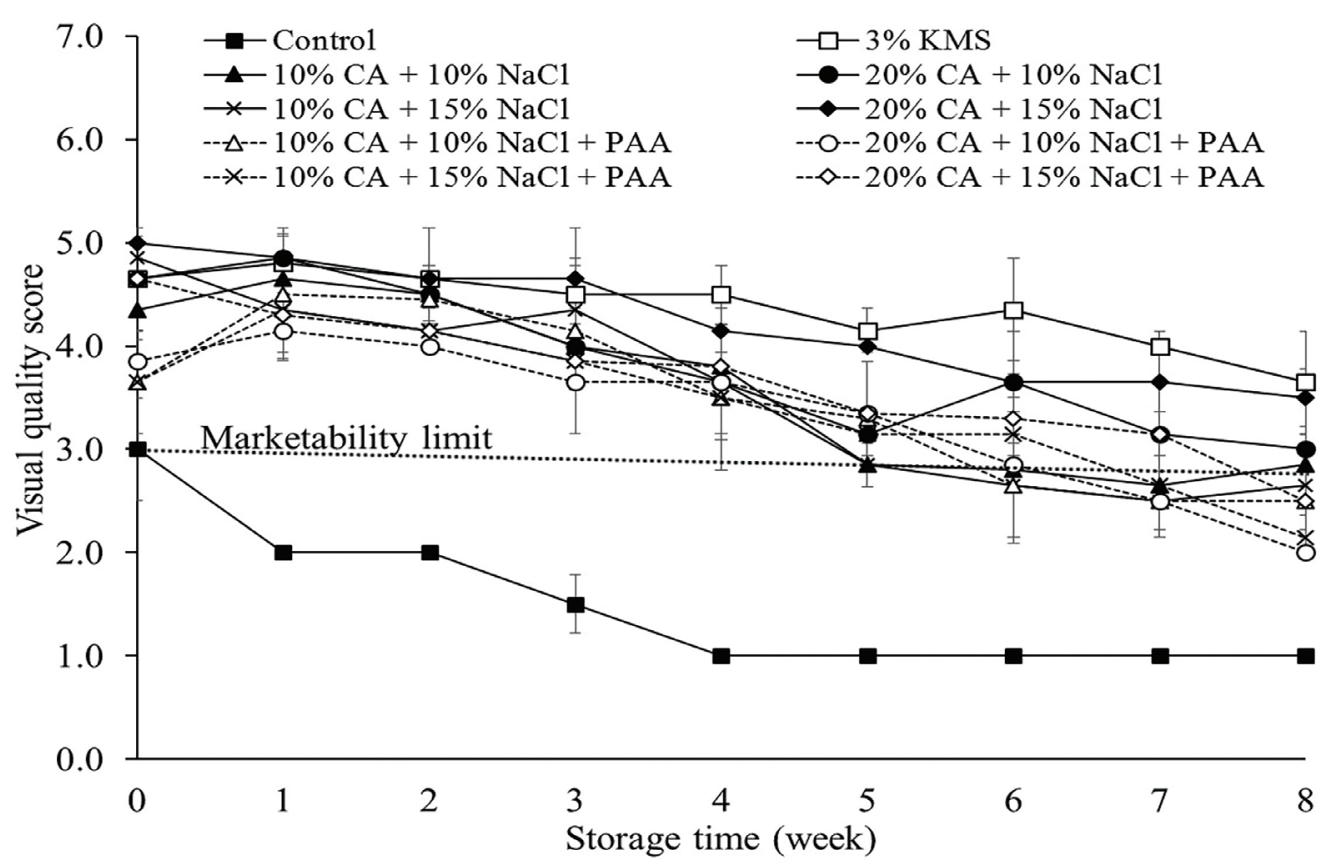

Figure 1. Visual quality of organic trimmed coconut dipped in different chemical treatments during storage at $2{ }^{\circ} \mathrm{C}$. Data are means of six replicates $\pm \mathrm{SE}$.

\section{Influence of treatments on color of organic trimmed aromatic coconut surface during storage}

The $\mathrm{L}^{*}$ values and $\mathrm{BI}$ values of treated coconuts all treatments did not significantly change $(P \geq 0.05)$ with storage time (Figure 2 and Figure 3$)$. SMS treatment gave the highest $\mathrm{L}^{*}$ values followed by $20 \% \mathrm{CA}+15 \% \mathrm{NaCl}$ and $20 \% \mathrm{CA}+10 \% \mathrm{NaCl}(P<0.05)$ (Figure 2$)$. $\mathrm{L}^{*}$ values of control samples were in range of $75.41-74.81$ (data not show) which were significantly lower than other treatments $(P<0.05)$. The result also showed that treatments with PAA gave significantly lower $L^{*}$ values compared to treatments without PAA.

BI values of control increased significantly (54.55 to 59.95) from week 0 to week 1 (data not show). Treatments with PAA resulted in yellowish color to the samples which gave higher BI values, when compared with other treatments without PAA. The BI values of treatment maintained during storage. Among alternative treatments, $20 \% \mathrm{CA}+10 \% \mathrm{NaCl}$ and $20 \% \mathrm{CA}+$ $15 \% \mathrm{NaCl}$ was better controlled browning on samples than the others.

The $\Delta \mathrm{E}^{*}$ of control and treatment with PAA increased significantly within the first week of storage period indicated quick color change in short term of 
storage $(P<0.05)$ (Figure 4). Treatments without PAA caused significantly lower color change than treatment with PAA $(P<0.05)$. However, treatments SMS, $20 \% \mathrm{CA}+10 \% \mathrm{NaCl}$ and $20 \% \mathrm{CA}+15 \% \mathrm{NaCl}$ maintained similar $\Delta \mathrm{E}^{*}$ values to each other, which were in range 1.44-2.34 during storage period $(P \geq 0.05)$.

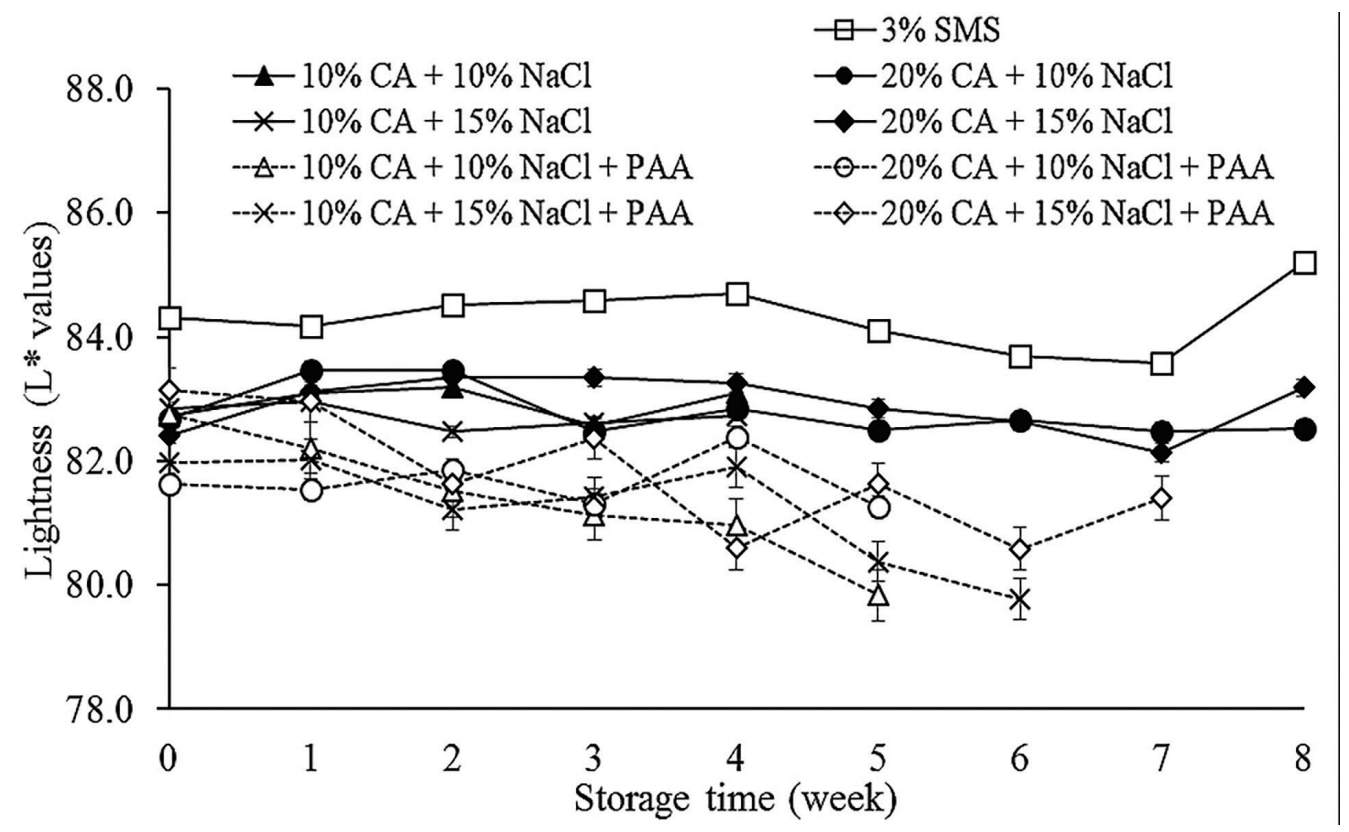

Figure 2. Lightness $\left(\mathrm{L}^{*}\right)$ values of organic trimmed coconut dipped in different chemical treatments during storage at $2{ }^{\circ} \mathrm{C}$. Data are means of six replicates $\pm \mathrm{SE}$. 


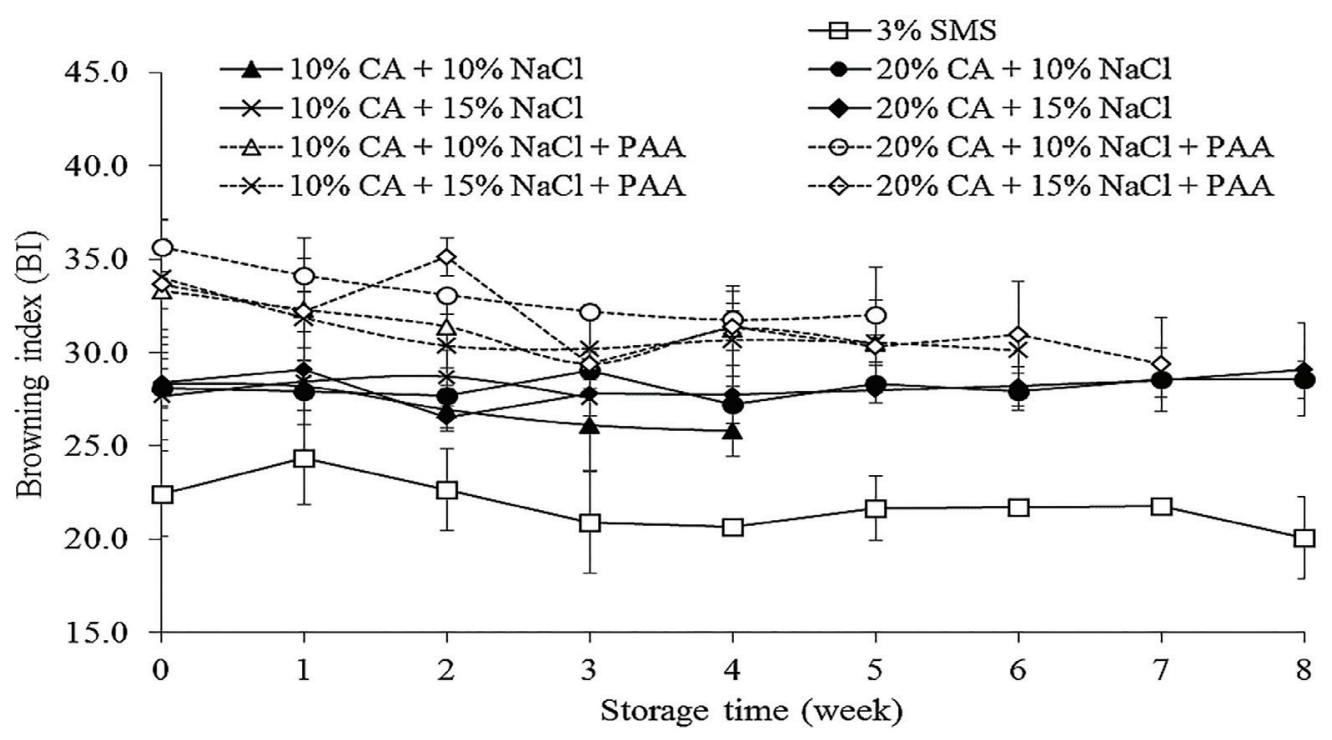

Figure 3. Browning index (BI) values of organic trimmed coconut dipped in different chemical treatments during storage at $2{ }^{\circ} \mathrm{C}$. Data are means of six replicates $\pm \mathrm{SE}$.

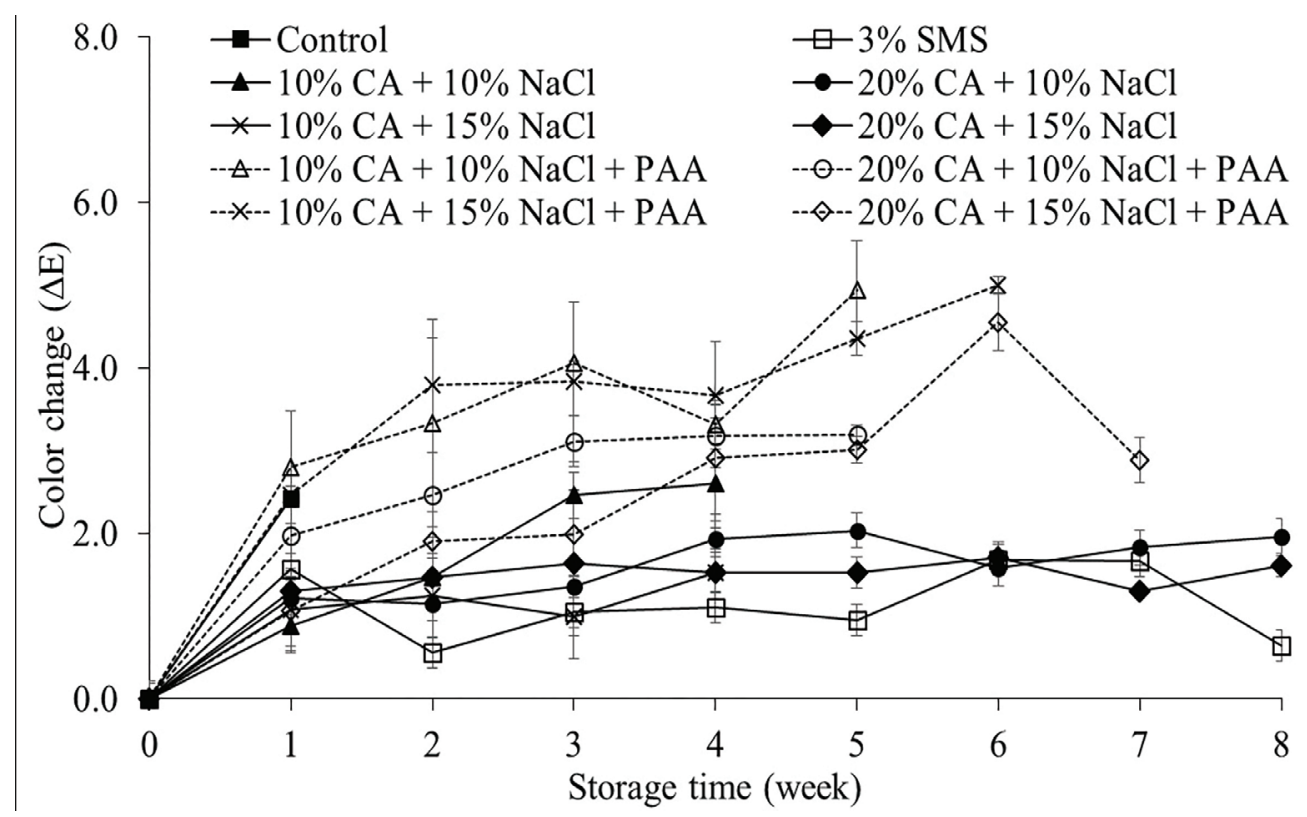

Figure 4. Color change $(\Delta \mathrm{E})$ values of organic trimmed coconut dipped in different chemical treatments during storage at $2{ }^{\circ} \mathrm{C}$. Data are means of six replicates $\pm \mathrm{SE}$. 


\section{Microbiological analysis}

The efficacy of alternative treatments were greatly affected by the concentration of both citric acid and $\mathrm{NaCl}$ on populations of mesophilic bacteria on trimmed organic aromatic coconut (Table 1). Treatment 20\% CA + $15 \% \mathrm{NaCl}$ gave a decrease of $1.7 \log \mathrm{CFU} /$ fruit at the first day of storage period when compared to control and maintained TPC during whole storage time, in range of 2.5-3.2 log CFU/fruit $(P \geq 0.05)$. There was no significant difference among SMS treatment and alternative treatments on the initial time of analyzing $(P \geq 0.05)$, however, TPC of alternative treatments continuously increased with storage time $(P<0.05)$.

PAA substantially influenced the TPC on organic trimmed aromatic coconuts after dipping in combination of citric acid and $\mathrm{NaCl}$ treatment. The TPC of with PAA treatments were maintained similar to SMS treatments until two weeks of storage time. However, PAA lost its capacity on control TPC of samples from week six until the end of storage. Their samples were rejected due to either microbial or sensorial quality.

Treatment $20 \% \mathrm{CA}+15 \% \mathrm{NaCl}$ and $20 \% \mathrm{CA}+10 \% \mathrm{NaCl}$ gave makeable effects on controlling TPC until the last day of storage period. However, $20 \% \mathrm{CA}+10 \% \mathrm{NaCl}$ samples had higher TPC (log CFU/fruit) compared to $20 \% \mathrm{CA}+15 \% \mathrm{NaCl}(2.8 \log \mathrm{CFU} /$ fruit $)$ at the end of storage time at $2{ }^{\circ} \mathrm{C}(P<0.05)$.

\section{Effect of treatments on titratable acidity (TA), pH and total soluble solids (TSS) on organic trimmed aromatic coconut water during storage}

The treatments did not significantly affected TA, $\mathrm{pH}$ and TSS of organic trimmed aromatic coconut water (Figure 5A, Figure 5B and Figure 5C) $(P<0.05)$. However, storage time significantly affected quality of coconut water $(P<0.05)$. As showed in the Figure 5A, although TA of coconut water dropped rapidly in the first week, there was no significant change $(P \geq 0.05)$ detected from week two until the last day of storage period, which was in the range of $0.035-0.048 \%$. The $\mathrm{pH}$ of coconut water slightly increased with the decrease in TA values during storage time $(P<0.05)$ (Figure 5A and 5B). The $\mathrm{pH}$ values of all treated samples increased gradually during the first 2-week storage $(P<0.05)$. Then, $\mathrm{pH}$ values of coconut water tended to remain until the last day of storage, which was in the range of 6.38-6.55. The TSS were in range 7.35$7.84{ }^{\circ}$ Brix during storage period (Figure $\left.5 \mathrm{C}\right)(P \geq 0.05)$. 


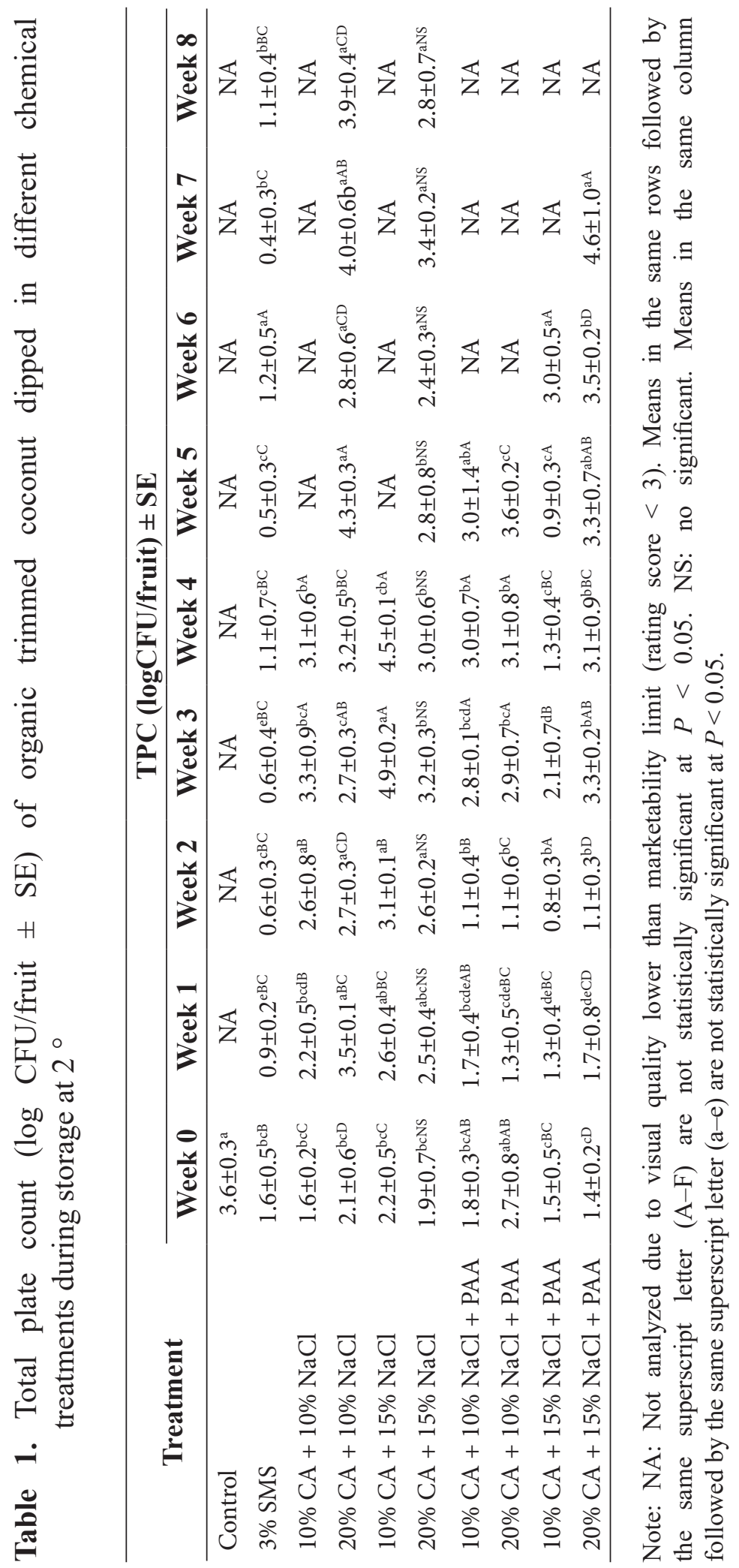



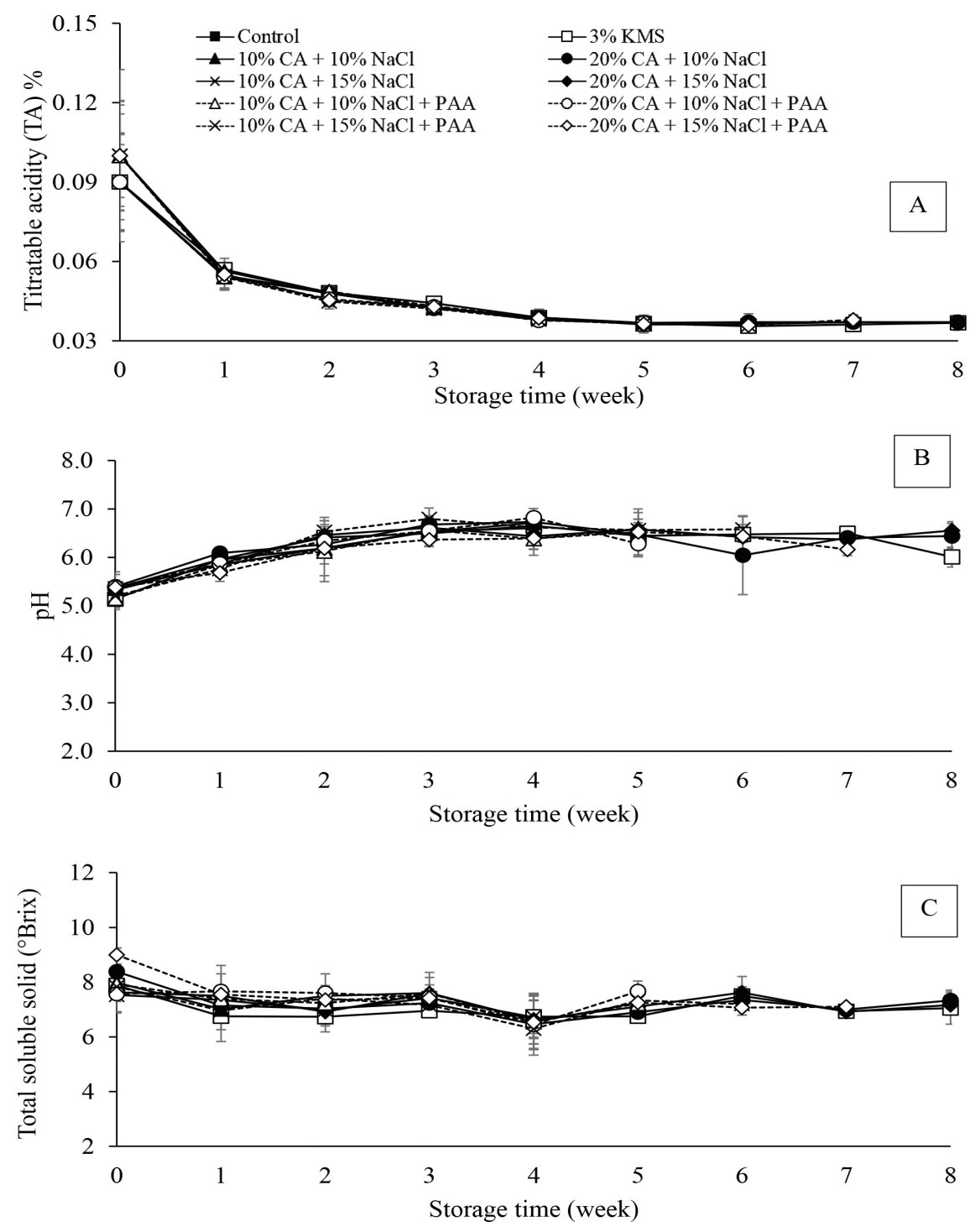

Figure 5. Titratable acidity (TA) (A), pH (B) and TSS (C) of organic trimmed coconut dipped in different chemical treatments during storage at $2{ }^{\circ} \mathrm{C}$. Data are means of six replicates $\pm \mathrm{SE}$. 


\section{DISCUSSION}

Citric acid (10\% and 20\%) and $\mathrm{NaCl}(10 \%$ and $15 \%)$ were selected for this study because preliminary study showed that lower concentrations than this range were not effective to inhibit browning and microbiological growth while higher concentration resulted in tissue injury. The results showed that beside SMS, $20 \% \mathrm{CA}+10 \% \mathrm{NaCl}$ and $20 \% \mathrm{CA}+15 \% \mathrm{NaCl}$ were the most effective treatments for maintaining quality of organic trimmed aromatic coconuts among all alternative treatments. Obviously, $20 \% \mathrm{CA}+15 \% \mathrm{NaCl}$ could be used for organic trimmed aromatic coconuts. The inhibit mechanism of $20 \% \mathrm{CA}+15 \% \mathrm{NaCl}$ and $\mathrm{SMS}$ on controlling browning were quite different. SMS worked as bleaching agent (Lambrecht, 1995) which caused lighter color to the surface of the fruits. Whereas, both citric acid and $\mathrm{NaCl}$ gave protective effect on maintaining colors, prolonging acceptable appearance and controlling TPC of the organic trimmed aromatic coconut. These findings also were in agreement with previous report in control enzymatic browning in tomato puree by combination of citric acid and $\mathrm{NaCl}$ (Plaza et al., 2003). Combination of $\mathrm{NaCl}$ and citric acid at high concentration could inhibit enzymatic browning in plants which catalyzed by PPO and POD (Watada et al., 1996). High concentration of citric acid resulted in lower $\mathrm{pH}$ environment and chelates the copper at the active site of the PPO. This inhibitory effect could be related to citric acid phenolase $\mathrm{Cu}$-chelating power. Especially, at $\mathrm{pH}$ values below 4, the looser binding of copper at the active enzyme site causes the PPO activity to decrease and permit citric acid to remove the copper (Wang et al., 2003; Altunkaya and Gökmen, 2009; Manolopoulou and Varzakas, 2011). Study of Manolopoulou and Varzakas (2011) reported that $1 \%$ citric acid treatment combined with low temperature storage $\left(0^{\circ} \mathrm{C}\right)$ prolonged the shelf life of minimally processed cabbage for 22 days. Higher concentration of citric acid (20\% in this study) helped maintain the color and overall acceptance and quality of organic trimmed aromatic coconut until 8 weeks of storage at $2{ }^{\circ} \mathrm{C}$. Browning inhibition effect of $\mathrm{NaCl}$ is attributed to the anion chloride. The action was reported as the noncompetitive reaction on inhibition PPO in apple (Janovitz-Klapp et al., 1990). Additionally, $\mathrm{Cl}^{-}$anions might interact with the dicopper center of PPO and replace the solvent ligand bridging the copper ions (Eicken et al., 1999). Nonetheless, $\mathrm{NaCl}$ had effect on enzymatic browning when added into substrate - enzyme system under acidic environment. At low $\mathrm{pH}, \mathrm{Cl}^{-}$and ionic strength were suggested to take responsibility for dramatic modifications of the enzyme conformation (Laurenti et al., 2000). 
The results also showed that PAA induced browning in samples which resulted in lower $\mathrm{L}^{*}$ values, higher $\mathrm{BI}$ and $\Delta \mathrm{E}^{*}$ values. This could be a result of tissue injury caused by PAA which lead to release enzyme from the cell to promote oxidation of phenolic compound. These results were also in agreement with Wang et al. (2007) and Ghidelli et al. (2013) .whom reported that treatments of PAA after treating with anti-browning agents were not effective in controlling browning in minimal processed persimmon and fresh-cut apple, respectively.

The TPC of samples treated by $20 \% \mathrm{CA}+15 \% \mathrm{NaCl}$ were maintained during storage at $2{ }^{\circ} \mathrm{C}$. High concentration of citric acid were reported to remain antimicrobial on stored iceberg lettuce (Akbas and Ölmez, 2007). The antimicrobial action of organic acids may depends on reduction in $\mathrm{pH}$, undissociated fraction of acid ratio, chain length, cell physiology and metabolism. Citric acid was more effective in reduction of mesophilic bacteria than lactic acid since it has more than one $\mathrm{COOH}$ group (Poli et al., 1979). In addition, $\mathrm{NaCl}$ most often works through dehydration, removing many of the water molecules in product that bacteria need to live and grow. By adding salt, the water product activity was lowered through osmosis process. Lowering product water activity to 0.91 is sufficiently to prevent most bacteria growth (Parish, 2006). Moreover, at greater concentration than $8.5 \%$ was reported to inhibit the survival or growth of E. coli O157:H7 (Glass et al., 1992). PAA could help to inhibit bacteria growth. PAA worked as a disinfectant oxidized the outer cell membranes of microorganisms. The oxidation mechanism consists of electron transfer. When a stronger oxidant is used, the electrons are transferred to the microorganism much faster which rapidly deactivated microorganism reaction (Kitis, 2004). However, in this study, treatment with PAA was only effective in controlling TPC in samples up to five weeks of storage. This may be due to insufficient contact time of sample with PAA solution. Concentration and contact time were important factors influencing microbial reduction of PAA treatment in fresh-cut produce (Vandekinderen et al., 2009).

The quality of organic trimmed aromatic coconut water changed gradually during storage at $2{ }^{\circ} \mathrm{C}$. Results showed a gradual increase in $\mathrm{pH}$ of coconut water during increase in storage period. Similar results were report in post-harvest coconut (Haseena et al., 2010). After 8-week storage, quality of coconut water in this study was still acceptable because unacceptable coconut water had the $\mathrm{pH}<5.75$ and TA $<0.02$ (Jangchud et al., 2007), .. Generally, $\mathrm{pH}$ values of all samples increased together with the decrease of the titratable acidity values while TSS values decreased slightly in the same storage period. It should be noted that the changes in TA, $\mathrm{pH}$ and TSS were not statistically significant $(P \geq 0.05)$ among different dipping treatments during storage. 


\section{CONCLUSION}

This study indicated that the combination treatment of $20 \% \mathrm{CA}+15 \%$ $\mathrm{NaCl}$ showed highest ability in extending the shelf-life and maintaining quality of trimmed organic coconut up to eight weeks of storage at $2{ }^{\circ} \mathrm{C}$. The results from this study could be used as an alternative dipping treatment to control the post-harvest deterioration for organic trimmed aromatic coconut.

\section{ACKNOWLEDGEMENTS}

The authors acknowledge the Department of Food Science and Technology, Faculty of Agro-Industry, Kasetsart University and K Fresh Co., Ltd., Thailand for funding support, laboratory equipment and facilities.

\section{REFERENCES}

Abadias, M., Alegre, I., Usall, J., Torres, R., and Viñas, I. 2011. Evaluation of alternative sanitizers to chlorine disinfection for reducing foodborne pathogens in fresh-cut apple. Postharvest Biology and Technology. 59(3): 289-297. https://doi.org/10.1016/j.postharvbio.2010.09.014

Akbas, M.Y., and Ölmez, H. 2007. Effectiveness of organic acid, ozonated water and chlorine dippings on microbial reduction and storage quality of fresh-cut iceberg lettuce. Journal of the Science of Food and Agriculture. 87(14): 2609-2616. https://doi.org/10.1002/jsfa.3016

Altunkaya, A., and Gökmen, V. 2009. Effect of various anti-browning agents on phenolic compounds profile of fresh lettuce (L. sativa). Food chemistry. 117(1): 122-126. https://doi.org/10.1016/j.foodchem.2009. 03.085

Amodio, M., Cabezas-Serranos, A., Rinaldi, R., and Colelli, G. 2007. Implementation of rating scales for visual quality evaluation of various vegetable crops. Retrieved from http://hdl.handle.net/11369/ 10071:

Anderton, A. 1986. Microbiological quality of products used in enteral feeds. Journal of Hospital Infection. 7(1): 68-73. https://doi.org/10.1016/ 0195-6701(86)90028-9

AOAC. 2000. Official methods of the association of official analytical chemists. Association of Official Analytical Chemists. Washington D.C. 
Cabezas-Serrano, A.B., Amodio, M.L., Cornacchia, R., Rinaldi, R., and Colelli, G. 2009. Screening quality and browning susceptibility of five artichoke cultivars for fresh-cut processing. Journal of the Science of Food and Agriculture. 89(15): 2588-2594. https://doi.org/10.1002/ jsfa.3759

CFR. 2011. Title 21, Part 173.315. Secondary direct food additives permitted in food for human consumption: chemicals used in washing or to assist in the peeling of fruits and vegetables. Code of Federal Regulations of US Food and Drug Administration. Retrieved from http://www.accessdata.fda.gov/scripts/cdrh/cfdocs/cfCFR/ CFRSearch.cfm

Eicken, C., Krebs, B., and Sacchettini, J.C. 1999. Catechol oxidase-structure and activity. Current opinion in structural biology. 9(6): 677-683. https://doi.org/10.1016/S0959-440X(99)00029-9

Fawell, J. 2000. Risk assessment case study-chloroform and related substances. Food and chemical toxicology 38: S91-S95. https://doi.org/ 10.1016/S0278-6915(99)00129-5

Ghidelli, C., Rojas-Argudo, C., Mateos, M., and Pérez-Gago, M.B. 2013. Effect of antioxidants in controlling enzymatic browning of minimally processed persimmon 'Rojo Brillante'. Postharvest Biology and Technology. 86: 487-493. http://dx.doi.org/10.1016/j.postharvbio.2013. 07.034

Glass, K., Loeffelholz, J., Ford, J., and Doyle, M. 1992. Fate of Escherichia coli $\mathrm{O} 157$ : $\mathrm{H} 7$ as affected by $\mathrm{pH}$ or sodium chloride and in fermented, dry sausage. Applied and Environmental Microbiology. 58(8): 2513-2516. http://aem.asm.org/cgi/content/short/58/8/2513

Haseena, M., Bai, K.K., and Padmanabhan, S. 2010. Post-harvest quality and shelf-life of tender coconut. Journal of Food Science and Technology. 47(6): 686-689.

Hunter, R.S., and Harold, R.W. 1987. The measurement of appearance. John Wiley \& Sons. New York

Jangchud, K., Puchakawimol, P., and Jangchud, A. 2007. Quality changes of burnt aromatic coconut during 28-day storage in different packages. LWT-Food Science and Technology. 40(7): 1232-1239. https://doi.org/ 10.1016/j.lwt.2006.08.014

Janovitz-Klapp, A.H., Richard, F.C., Goupy, P.M., and Nicolas, J.J. 1990. Inhibition studies on apple polyphenol oxidase. Journal of Agricultural and Food Chemistry. 38(4): 926-931. https://pubs.acs.org/doi/pdf/10. 1021/jf00094a002 
Javdani, Z., Ghasemnezhad, M., and Zare, S. 2013. A comparison of heat treatment and ascorbic acid on controlling enzymatic browning of fresh-cuts apple fruit. International Journal of Agriculture and Crop Sciences. 5(3): 2227-2670X.

Kitis, M. 2004. Disinfection of wastewater with peracetic acid: a review. Environment International. 30(1): 47-55. https://doi.org/10.1016/S01604120(03)00147-8

Lambrecht, H. 1995. Sulfite substitutes for the prevention of enzymatic browning in foods. In: Lee, C.Y. and Whitaker J.R., editors. Enzymatic Browning and its Prevention in Enzymatic Browning and its Prevention. ACS Symposium Series Vol. 600. p. 313-323. http://doi.org/ 10.1021/bk-1995-0600.ch024

Laurenti, E., Suriano, G., Ghibaudi, E.M., and Ferrari, R.P. 2000. Ionic strength and $\mathrm{pH}$ effect on the $\mathrm{Fe}(\mathrm{III})$-imidazolate bond in the heme pocket of horseradish peroxidase: an EPR and UV-visible combined approach. Journal of Inorganic Biochemistry. 81(4): 259-266. https://doi.org/10. 1016/S0162-0134(00)00124-0

Lu, S., Luo, Y., Turner, E., and Feng, H. 2007. Efficacy of sodium chlorite as an inhibitor of enzymatic browning in apple slices. Food Chemistry. 104(2): 824-829. http://dx.doi.org/10.1016/j.foodchem.2006.12.050

Manolopoulou, E., and Varzakas, T. 2011. Effect of storage conditions on the sensory quality, colour and texture of fresh-cut minimally processed cabbage with the addition of ascorbic acid, citric acid and calcium chloride. Food and Nutrition Sciences. 2(9): 956-963. http://doi.org/ 10.4236/fns.2011.29130

Mohpraman, K., and Siriphanich, J. 2012. Safe use of sodium metabisulfite in young coconuts. Postharvest Biology and Technology. 65: 76-78. http://dx.doi.org/10.1016/j.postharvbio.2011.11.006

Parish, M. 2006. How do salt and sugar prevent microbial spoilage? Scientific American. 294(5): 98-98.

Park, S.H., Choi, M.R., Park, J.W., Park, K.H., Chung, M.S., Ryu, S., and Kang, D.H. 2011. Use of organic acids to inactivate Escherichia coli O157: H7, Salmonella Typhimurium, and Listeria monocytogenes on organic fresh apples and lettuce. Journal of Food Science. 76(6): 293-298. https://doi.org/10.1111/j.1750-3841.2011.02205.x

Plaza, L., Muñoz, M., de Ancos, B., and Cano, M.P. 2003. Effect of combined treatments of high-pressure, citric acid and sodium chloride on quality parameters of tomato puree. Europ an Food Research and Technology. 216(6): 514-519. https://doi.org/10.1007/s00217-003-0689-0 
Poli, G., Biondi, P.A., Uberti, F., Ponti, W., Balsari, A., and Cantoni, C. 1979. Virucidal activity of organic acids. Food Chemistry. 4(4): 251-258. https://doi.org/10.1016/0308-8146(79)90012-8

Vally, H., Misso, N.L., and Madan, V. 2009. Clinical effects of sulphite additives. Clinical \& Experimental Allergy. 39(11): 1643-1651. https://doi.org/ 10.1111/j.1365-2222.2009.03362.x

Vandekinderen, I., Devlieghere, F., De Meulenaer, B., Ragaert, P., and Van Camp, J. 2009. Optimization and evaluation of a decontamination step with peroxyacetic acid for fresh-cut produce. Food Microbiology. 26(8): 882-888. https://doi.org/10.1016/j.fm.2009.06.004

Wang, H., Feng, H., and Luo, Y. 2007. Control of browning and microbial growth on fresh-cut apples by sequential treatment of sanitizers and calcium ascorbate. Journal of Food Science. 72(1): M1-M7. https://doi.org/10.1111/j.1750-3841.2006.00210.x

Wang, L.F., Kim, D.M., Park, J.D., and Lee, C.Y. 2003. Various antibrowning agents and green tea extract during processing and storage. Journal of Food Processing and Preservation. 27(3): 213-225. https://doi.org/10.1111/j.1745-4549.2003.tb00513.x

Watada, A.E., Ko, N.P., and Minott, D.A. 1996. Factors affecting quality of fresh-cut horticultural products. Postharvest Biology and Technology. 9(2): 115-125.

Winter, C.K., and Davis, S.F. 2006. Organic foods. Journal of Food Science. 71(9): 1750-3841. https://doi.org/10.1111/j.1750-3841.2006.00196.x 